\title{
A Study of the Temperature Influence on Different Parameters of Mono-Crystalline Silicon Photovoltaic Module
}

\author{
Said Amar1,2*, Mustapha Bahich ${ }^{3}$, Youness Bentahar ${ }^{1}$, Mohamed Afifi', Elmostapha Barj1 \\ ${ }^{1}$ Physics Department, Faculty of Sciences Ben Msik, Hassan II University, Casablanca, Morocco \\ ${ }^{2}$ SIPE Laboratory, ENSA, Chouaib Doukkali University, El Jadida, Morocco \\ ${ }^{3}$ Physics Department, Faculty of Sciences, Moulay Ismail University, Meknes, Morocco \\ Email: ^dramarsaid@gmail.com
}

How to cite this paper: Amar, S., Bahich, M., Bentahar, Y., Afifi, M. and Barj, E. (2021) A Study of the Temperature Influence on Different Parameters of Mono-Crystalline Silicon Photovoltaic Module. Journal of Power and Energy Engineering, 9, 29-42. https://doi.org/10.4236/jpee.2021.96003

Received: February 17, 2021

Accepted: June 14, 2021

Published: June 17, 2021

Copyright $\odot 2021$ by author(s) and Scientific Research Publishing Inc. This work is licensed under the Creative Commons Attribution International License (CC BY 4.0).

http://creativecommons.org/licenses/by/4.0/ (c) (i) Open Access

\begin{abstract}
In this article, the effect of temperature on the photovoltaic parameters of mono-crystalline silicon Photovoltaic Panel is undertaken, using the Matlab environment with varying module temperature in the range $25^{\circ} \mathrm{C}-60^{\circ} \mathrm{C}$ at constant solar irradiations $200-500 \mathrm{~W} / \mathrm{m}^{2}$. The results show that the temperature has a significant impact on the various parameters of the photovoltaic panel and it controls the quality and performance of the solar panel. The photovoltaic parameters are the current of short circuit $I_{s o}$ the open circuit voltage $V_{c o}$, the form factor FF, the maximum power $P_{\max }$ as well as efficiency. The relative change of these photovoltaic parameters with temperature is also evaluated in this article. A DS-100M solar panel has been used as reference model. The results show also that the open circuit voltage, maximum power, fill factor and efficiency decrease with temperature, but the short circuit current increases with temperature. The results are in good agreement with the available literature.
\end{abstract}

\section{Keywords}

Module Temperature, Photovoltaic Parameters, Solar Irradiation, Solar Panel

\section{Introduction}

Photovoltaic solar energy results from the direct transformation of solar radiation into electrical energy. This energy conversion is done using a photovoltaic cell (PV) based on a physical phenomenon known as the photovoltaic effect which consists in producing a potential difference when the surface of this cell is exposed to light. The voltage generated depends on the material used to make 
the cell.

The PV cell constitutes an electric generator of very low power compared to the needs of domestic or industrial applications. A photovoltaic cell of a few tens of square centimeters delivers at most a few watts at very low voltage (of the order of 0.6 to $0.8 \mathrm{~V}$ ), which is precisely a PN junction voltage. To increase the operating voltage and increase the power available at the level of the photovoltaic cell, they are connected in series and/or in parallel to obtain a photovoltaic module.

Mono-crystalline silicon ( $\mathrm{mc}-\mathrm{Si}$ ) solar module is mostly used to solar modules because it has a number of advantages like low maintenance cost, high reliability, noiseless and eco-friendly [1] [2]. The overall performance of the mc-Si solar module is highly dependent on environmental parameters, such as light intensity, tracking angle and module temperature [3]. Although photovoltaic parameters such as open circuit voltage, short circuit current, maximum output power, fill factor and efficiency are generally affected by temperature.

A study of the electrical characteristics of diodes of crystalline silicon cells with cell temperature was worked by [4]. They found that the ideality factor decreases with cell temperature in the space charge region and increases in the quasi-neutral region. [5] studied the dependence of cell temperature on characteristics of different solar cells using the linear interpolation method and observed that the physical validity of linear interpolation for cell temperature was based on the current-voltage characteristics of the junction p-n. [6] studied the influence of cell temperature on the series resistance of silicon solar cells and observed that the series resistance varies with cell temperature; therefore, the temperature of the cell is a key parameter to judge the quality and crystalline silicon solar cell performance [7] [8]. The expression of current-voltage of a crystalline silicon solar cell [3] is:

$$
I=I_{0}\left[\exp \left(\frac{q\left(V-I R_{s}\right)}{n k T}\right)-1\right]+\left(V-\frac{I R_{s}}{R_{s h}}\right)-I_{L}
$$

Here, $I_{0}$ is the reverse saturation current, $q$ is the electron charge, $n$ is the ideality factor of the diode, $T$ is the temperature, $k$ is the Boltzmann constant, $R_{s h}$ is the shunt resistance, $R_{s}$ is the series resistance and $I_{L}$ is the light generated current of the silicon solar cell. To control the quality and determine the performances of a solar module, precise knowledge of the environmental parameters is necessary. Environmental parameters always play an important role in the performance characteristics of silicon solar modules. Therefore, it is necessary to study these parameters with precision. All the work proposed above does not present the step-by-step simulation procedure for the study of these parameters and this leads to difficulties for the readers to follow and to make the simulations by themselves.

Consequently, our study is interested on the influence of the temperature on the photovoltaic parameters of the mc-Si solar module using the Matlab/simulink environment. The manipulations were undertaken for module 
temperatures $25^{\circ} \mathrm{C}, 40^{\circ} \mathrm{C}, 50^{\circ} \mathrm{C}$ and $60^{\circ} \mathrm{C}$ at the constant light intensities 200 , 300,400 and $500 \mathrm{~W} / \mathrm{m}^{2}$ for studying the influence of temperature on the different parameters of solar module.

\section{Presentation and Modeling of PV Module}

\subsection{The Equivalent Circuit}

The equivalent circuit of the PV cell is represented in Figure 1. The current source $I_{p h}$ represents the photocurrent of the cell. $R_{s h}$ and $R_{s}$ are respectively the shunt and series resistors of the cell. Usually the value of $R_{s h}$ is very large and that of $R_{s}$ is very small, so they can be neglected to simplify the analysis [9]. Practically, PV cells are grouped into larger units to build PV modules and these modules are also connected in series or parallel to create PV panels which are used to generate electricity in PV production systems. The equivalent circuit for the photovoltaic panel is shown in Figure 2.

The voltage-current characteristic equation of a solar cell is provided as [10]

$$
I_{p h}=\left[I_{s c}+K_{i}(T-298)\right] \times I_{r} / 1000
$$

In this last relation, $I_{p h}$ represents the photo-current (A); $I_{s c}$ : the short-circuit current (A); $K_{i}$ : the short-circuit current of the cell at $25^{\circ} \mathrm{C}$ and $1000 \mathrm{~W} / \mathrm{m}^{2} ; T$ : the operating temperature $(\mathrm{K}) ; I_{r}$ : the solar irradiation $\left(\mathrm{W} / \mathrm{m}^{2}\right)$.

Reverse saturation current $I_{r s}$ of the module is given by the relation:

$$
I_{r s}=I_{s c} /\left[\exp \left(q V_{o c} / N_{s} K n T\right)-1\right]
$$

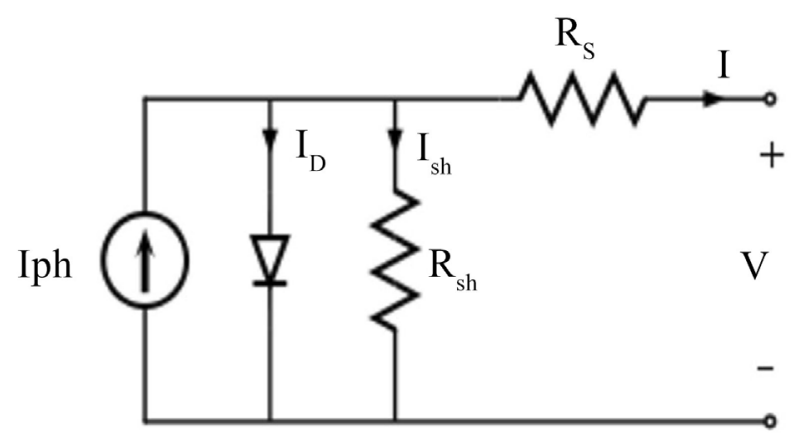

Figure 1. PV cell equivalent circuit [11].

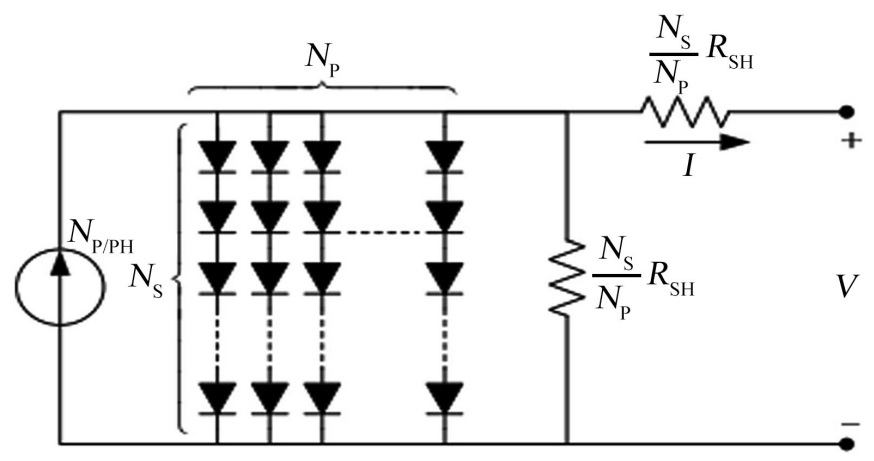

Figure 2. Equivalent circuit of solar array [10]. 
Here, $q$ : the electron charge, $=1.602 \times 10^{-19} \mathrm{C} ; V_{o c}$ the open circuit voltage $(\mathrm{V})$; $N_{s}$ : number of cells connected in series; $n$ : the ideality factor of the diode; $k$. Boltzmann's constant $=1.38 \times 10^{-23} \mathrm{~J} / \mathrm{K}$.

The module saturation current $I_{0}$ varies with the temperature of the cell, which is given by:

$$
I_{0}=I_{r s}\left[\frac{T}{T_{r}}\right]^{3} \exp \left[\frac{q \times E_{g 0}}{n K}\left(\frac{1}{T}-\frac{1}{T_{r}}\right)\right]
$$

Here, $T_{r}$ : the nominal temperature $=298.15 \mathrm{~K} ; E_{g 0}$ : The band gap energy of the semiconductor, $=1.1 \mathrm{eV}$; The output current of the PV panel is:

$$
I=N_{P} \times I_{p h}-N_{P} \times I_{0} \times\left[\exp \left(\frac{\frac{V}{N_{S}}+I \times R_{S} / N_{P}}{n \times V_{t}}\right)-1\right]-I_{s h}
$$

With

$$
V_{t}=\frac{K \times T}{q}
$$

where $V_{t}$ is called the thermal voltage [12]

And

$$
I_{s h}=\frac{V \times \frac{N_{P}}{N_{S}}+I \times R_{S}}{R_{s h}}
$$

Here: $N_{p}$ : number of PV modules connected in parallel; $R_{s}$ : series resistance $(\Omega) ; R_{s h}$ : shunt resistance $(\Omega) ; V_{i}$ thermal voltage of the diode $(\mathrm{V})$.

The open circuit voltage $\left(V_{o c}\right)$ depends on the temperature and is given by the following relationship [2].

$$
V_{o c}=\frac{E_{g}}{k}-\frac{n k T}{q} \ln \frac{I_{0 \max }}{I_{s c}}
$$

In this equation, $E_{g}$ is the energy band gap and $I_{0 \max }$ is the maximum reverse saturation current. The fill factor $(F F)$ is given by the following relation [13].

$$
F F=\frac{P_{\max }}{V_{o c} \times I_{s c}}
$$

In this equation $P_{\max }$ is the maximum Power. The efficiency of solar module is given [14]

$$
\eta_{M}=\frac{P_{\max }}{E * A_{a}} * 100
$$

where $P_{\max }$ is the measured output Power, $E$ is the irradiance and $A_{a}$ is the module active area.

The dependence between cell temperature and efficiency is given [7] as follows: 


$$
\eta_{C}=\eta_{\text {Tref }}\left[1-\beta_{0}\left(T_{c}-T_{r e f}\right)\right]
$$

In this equation $\eta_{c}$ and $\eta_{\text {Tref }}$ are efficiencies of solar cell at cell temperature and room temperature respectively, $\beta_{0}$ is the efficiency temperature coefficient $(0.002$ $\left.\mathrm{k}^{-1}\right), T_{c}$ and $T_{\text {ref }}$ are the cell temperature and the reference temperature of solar cell respectively.

\subsection{Reference Model}

The $100 \mathrm{~W}$ solar power module is taken as the reference module for the simulation and the detailed module parameters are given in Table 1 . The electrical specifications are under test conditions of irradiance of $1 \mathrm{~kW} / \mathrm{m}^{2}$, spectrum of 1.5 air masses and cell temperature of $25^{\circ} \mathrm{C}$.

\subsection{Step by Step Procedure for Modeling Photovoltaic Modules with Tags}

A mathematical model of the photovoltaic generator including the fundamental components of the diode, current source, series resistor and parallel resistor is modeled with tags in the Simulink environment. The simulation of the solar module is based on the equations given in the section above and performed in the following steps.

- Step 1

The input parameters for modeling are as follows:

$T_{r}$ is the reference temperature $=298.15 \mathrm{~K} ; n$ is the ideality factor $=1.2 ; k$ is Boltzmann's constant $=1.3805 \times 10^{-23} \mathrm{~J} / \mathrm{K} ; q$ is the elementary charge $=1.6 \times$ $10^{-19} \mathrm{C} ; I_{s c}$ is the short-circuit current of the PV module at $25^{\circ} \mathrm{C}$ and $1000 \mathrm{~W} / \mathrm{m}^{2}$ $=6.11 \mathrm{~A} ; V_{o c}$ is the open circuit voltage of the PV module at $25^{\circ} \mathrm{C}$ and 1000 $\mathrm{W} / \mathrm{m}^{2}=0.6 \mathrm{~V} ; E_{g 0}$ is the energy of the band gap for silicon $=1.1 \mathrm{eV} . R_{s}$ is a series resistance, normally of very small value, $=0.0001 \Omega ; R_{s h}$ is the shunt resistance of such a large value, $=1000 \Omega$.

- Step 2

The photon current of the module is given in Equation (2) and modeled as Figure 3.

Table 1. Electrical characteristics data of DS-100M PV module [15].

\begin{tabular}{cc}
\hline Name & DS-100M \\
\hline Rated power $V_{m p}$ & $100 \mathrm{~W}$ \\
Voltage at maximum power $V_{m p}$ & $18 \mathrm{~V}$ \\
Current at maximum power $I_{m p}$ & $5.55 \mathrm{~A}$ \\
Open circuit voltage $V_{o c}$ & $21.6 \mathrm{~V}$ \\
Short circuit current $I_{s c}$ & $6.11 \mathrm{~A}$ \\
Total number of cells in series $\left(N_{S}\right)$ & 36 \\
Total number of cells in parallel $\left(N_{P}\right)$ & 1 \\
Maximum system voltage & $1000 \mathrm{~V}$ \\
Range of operation temperature & $-40^{\circ} \mathrm{C}$ to $80^{\circ} \mathrm{C}$ \\
Area & $1100 \times 0.665 \mathrm{~m}^{2}$ \\
\hline
\end{tabular}




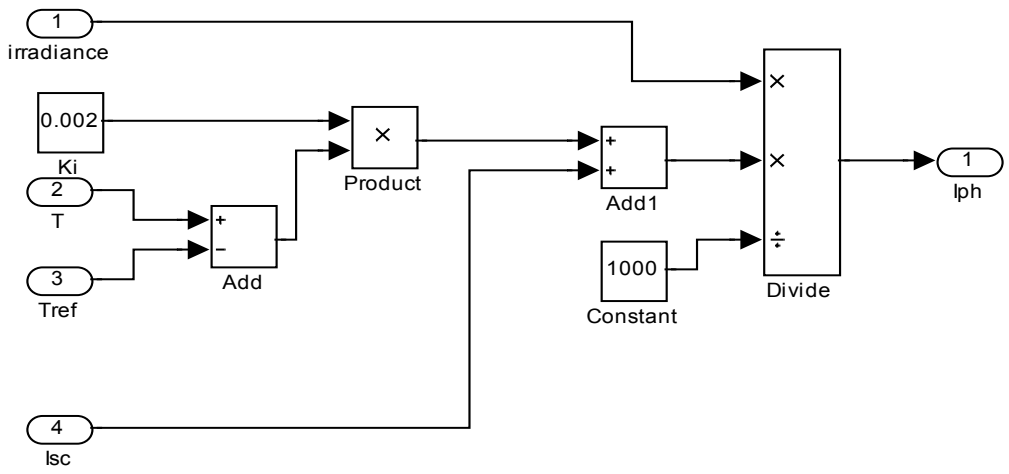

Figure 3. Modeled circuit for Equation (2).

$$
I_{p h}=\left[I_{s c}+K_{i}(T-298)\right] \times I_{r} / 1000
$$

- Step 3

The reverse saturation current of the module is given in Equation (3) and modeled as Figure 4.

- Step 4

The saturation current $I_{0}$ of the module is given in Equation (4) and modeled as Figure 5.

- Step 5

Modeled circuit for Equation (6) and modeled as Figure 6.

- Step 6

Modeled circuit for Equation (7) and modeled as Figure 7.

To obtain the output current $I$ of the solar system, we model the Equation (5), the result is shown in Figure 8.

\section{Results and Discussion}

With the developed model, the characteristics of the PV module are estimated as follows. The I-V and P-V characteristics under variable temperature at constant irradiation are given in Figure 9. Here, the temperature changes with values of $25^{\circ} \mathrm{C}, 40.50^{\circ} \mathrm{C}$ and $60^{\circ} \mathrm{C}$ while the solar irradiation remains constant at 200,300 , 400 and $500 \mathrm{~W} / \mathrm{m}^{2}$.

It is clear from Figures 9(a)-(d) that the current-voltage and power-voltage characteristics depend on the temperature of the module. In the current-voltage characteristics, it is observed that the current is maximum and almost constant in the lower voltage range and varies with the cell temperature in the range 1.222 - $1.236 \mathrm{~A}, 1.833-1.854 \mathrm{~A}, 2.444-2.472 \mathrm{~A}$ and $3.055-3.090 \mathrm{~A}$ at constant irradiations $200 \mathrm{~W} / \mathrm{m}^{2}, 300 \mathrm{~W} / \mathrm{m}^{2}, 400 \mathrm{~W} / \mathrm{m}^{2}$ and $500 \mathrm{~W} / \mathrm{m}^{2}$ respectively.

The estimation of the characteristics follows the order of the temperature of the module as the successive higher underestimates the lower one. The trend is reversed for the voltage intervals $7.8-11.52 \mathrm{~V}, 8.28-12 \mathrm{~V}, 8.64-12.24 \mathrm{~V}$ and $8.88-12.54 \mathrm{~V}$ for the irradiations of $200 \mathrm{~W} / \mathrm{m}^{2}, 300 \mathrm{~W} / \mathrm{m}^{2}, 400 \mathrm{~W} / \mathrm{m}^{2}$ and 500 $\mathrm{W} / \mathrm{m}^{2}$ respectively. Subsequently, it is found that the current decreases rapidly and the characteristics corresponding to a successive lower module temperature exist beyond the higher one. 


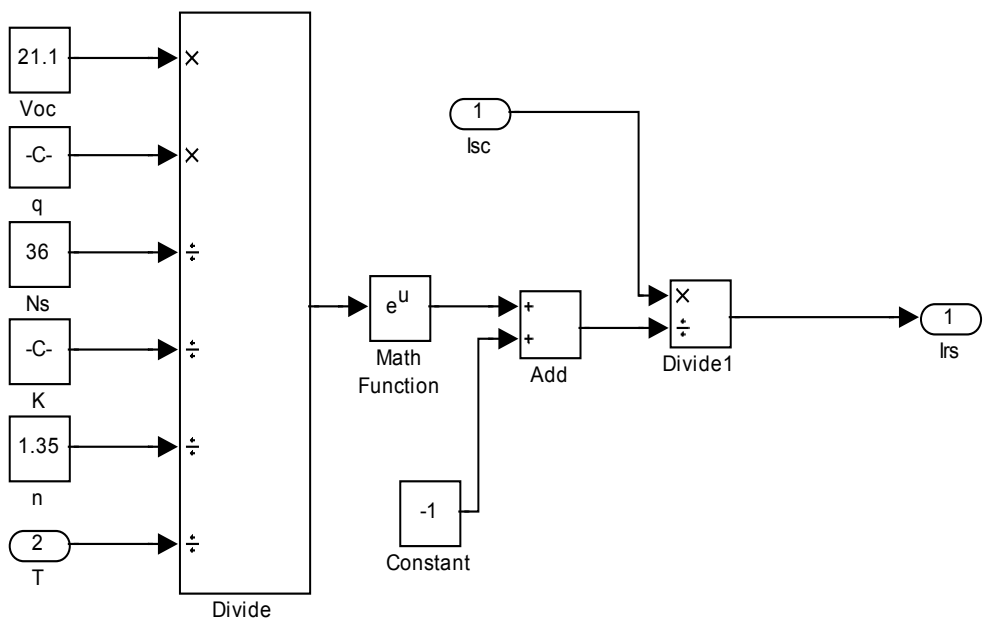

Figure 4. Modeled circuit for Equation (3).

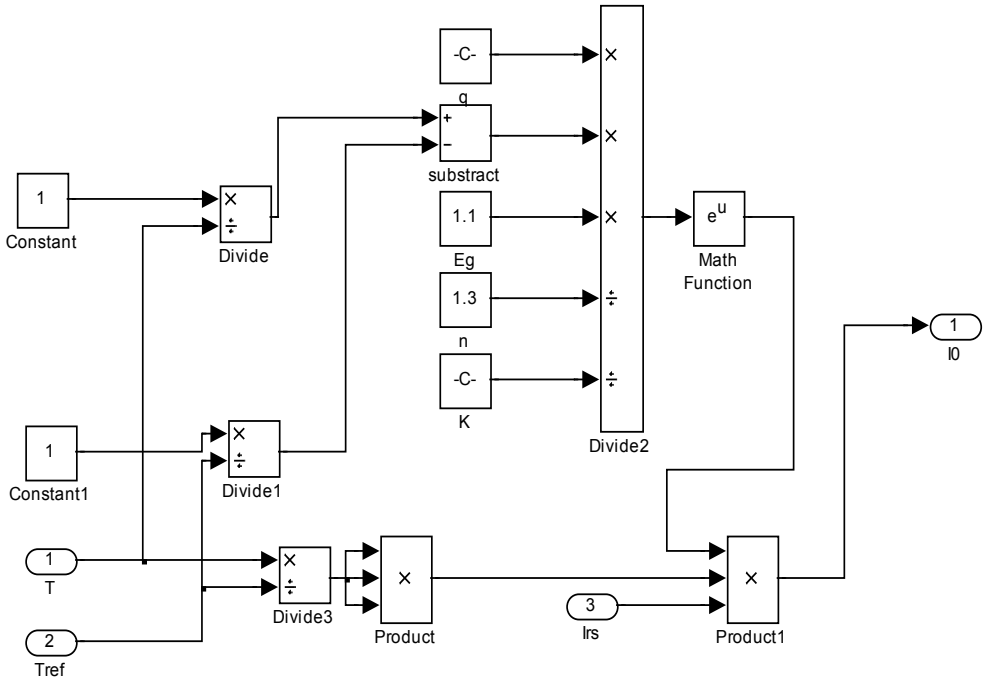

Figure 5. Modeled circuit for Equation (4).

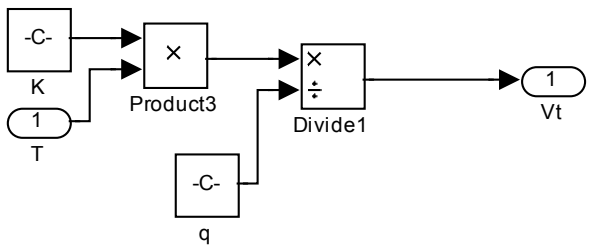

Figure 6. Modeled circuit for Equation (6).

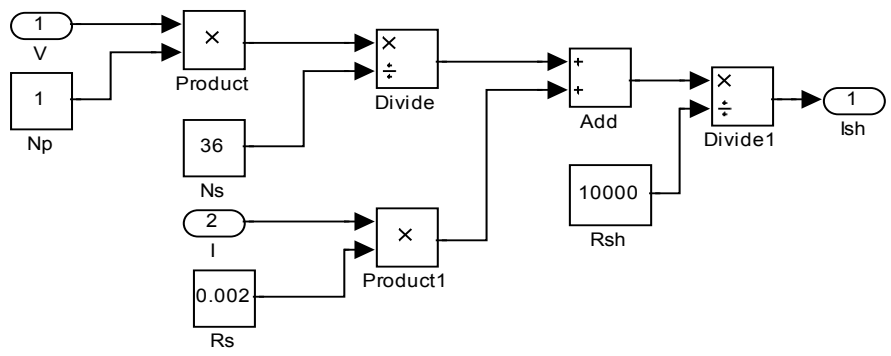

Figure 7. Modeled circuit for Equation (7). 


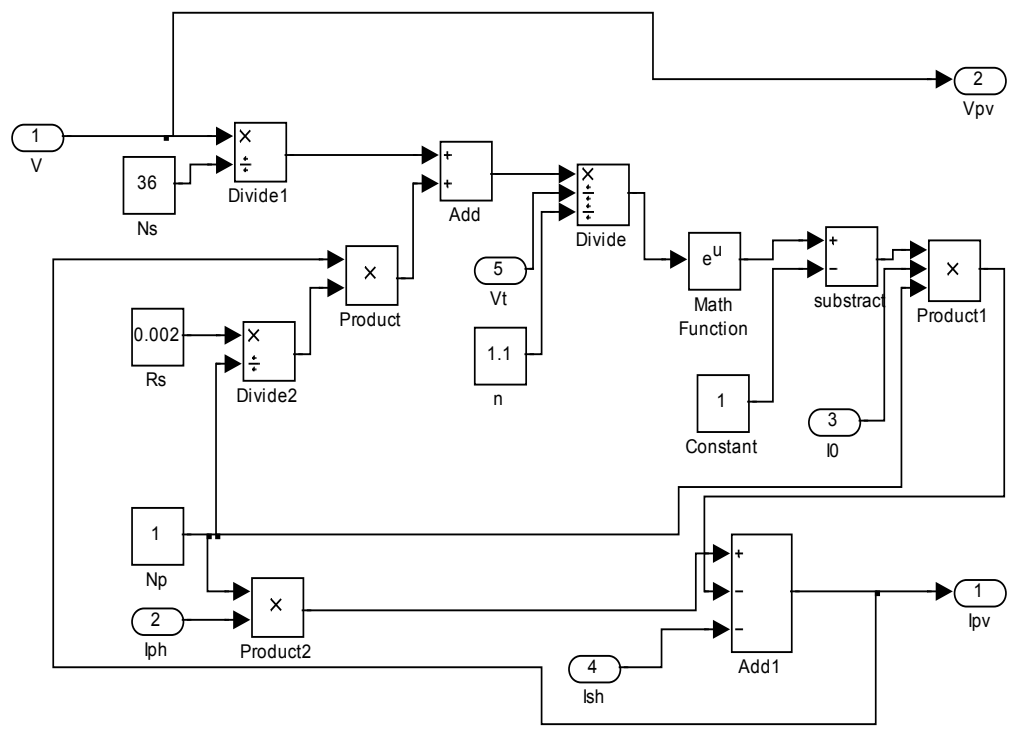

Figure 8. Modeled circuit for Equation (5).
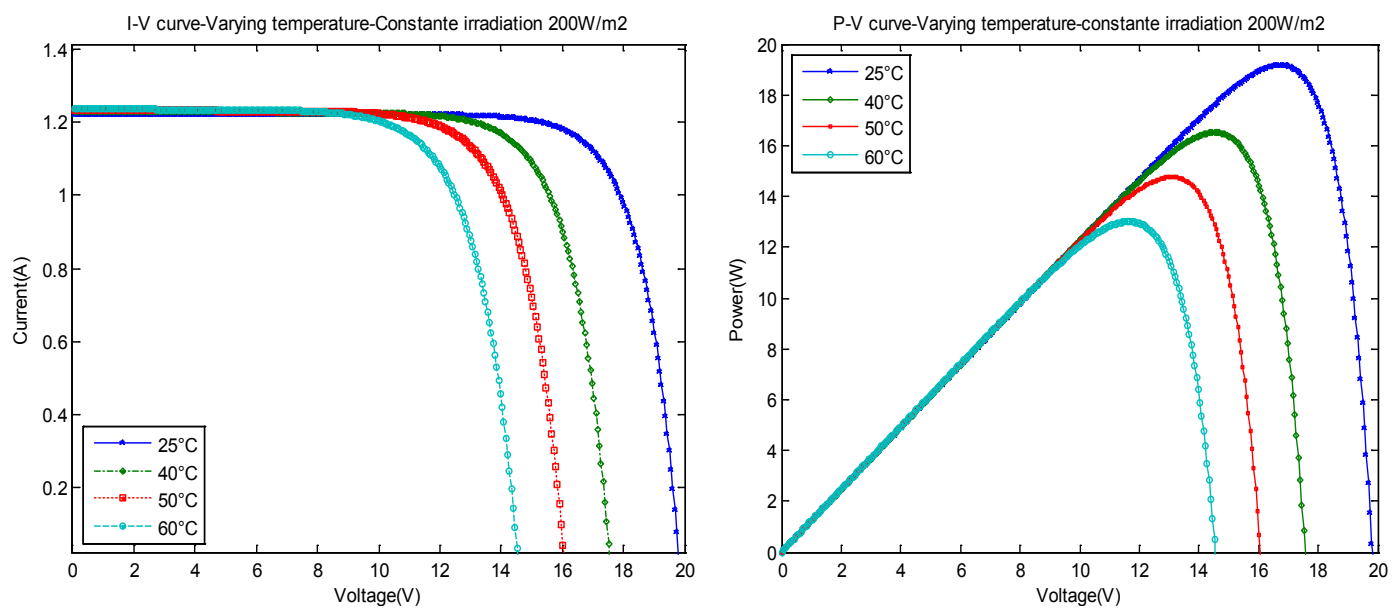

(a) Irradiation at $200 \mathrm{~W} / \mathrm{m}^{2}$.
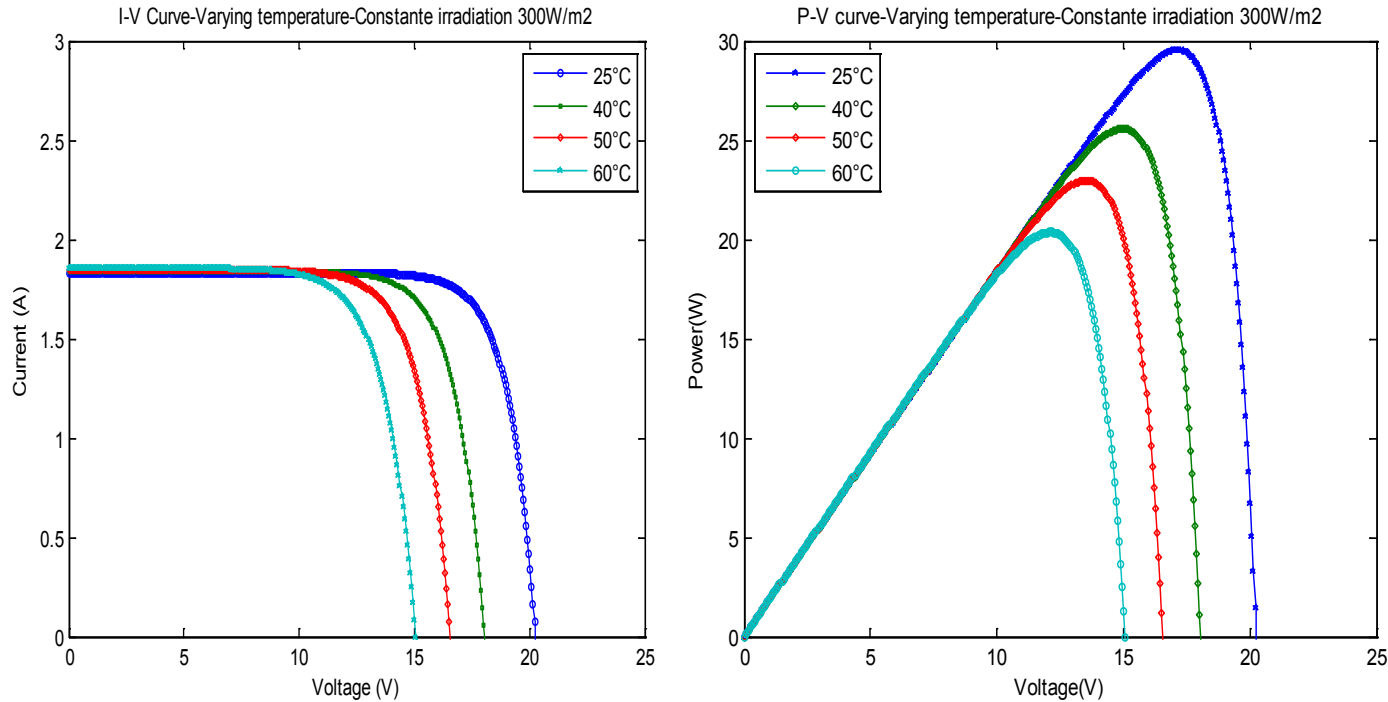

(b) Irradiation at $300 \mathrm{~W} / \mathrm{m}^{2}$. 

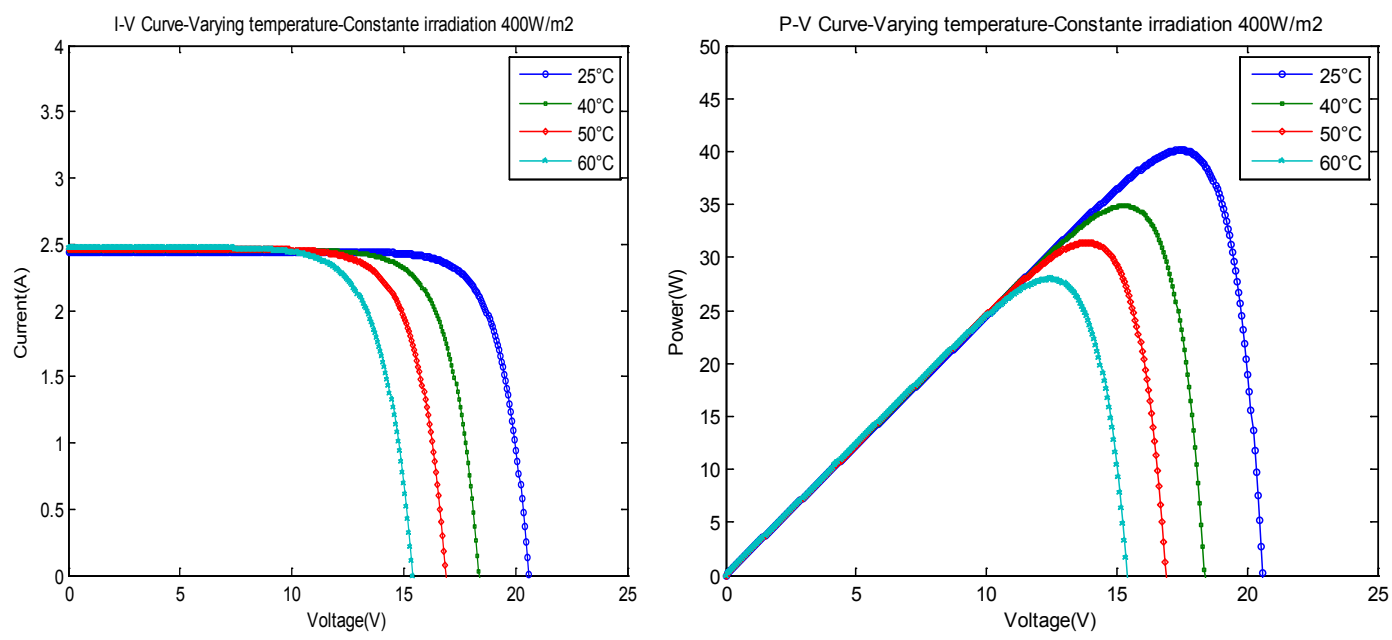

(c) Irradiation at $400 \mathrm{~W} / \mathrm{m}^{2}$.
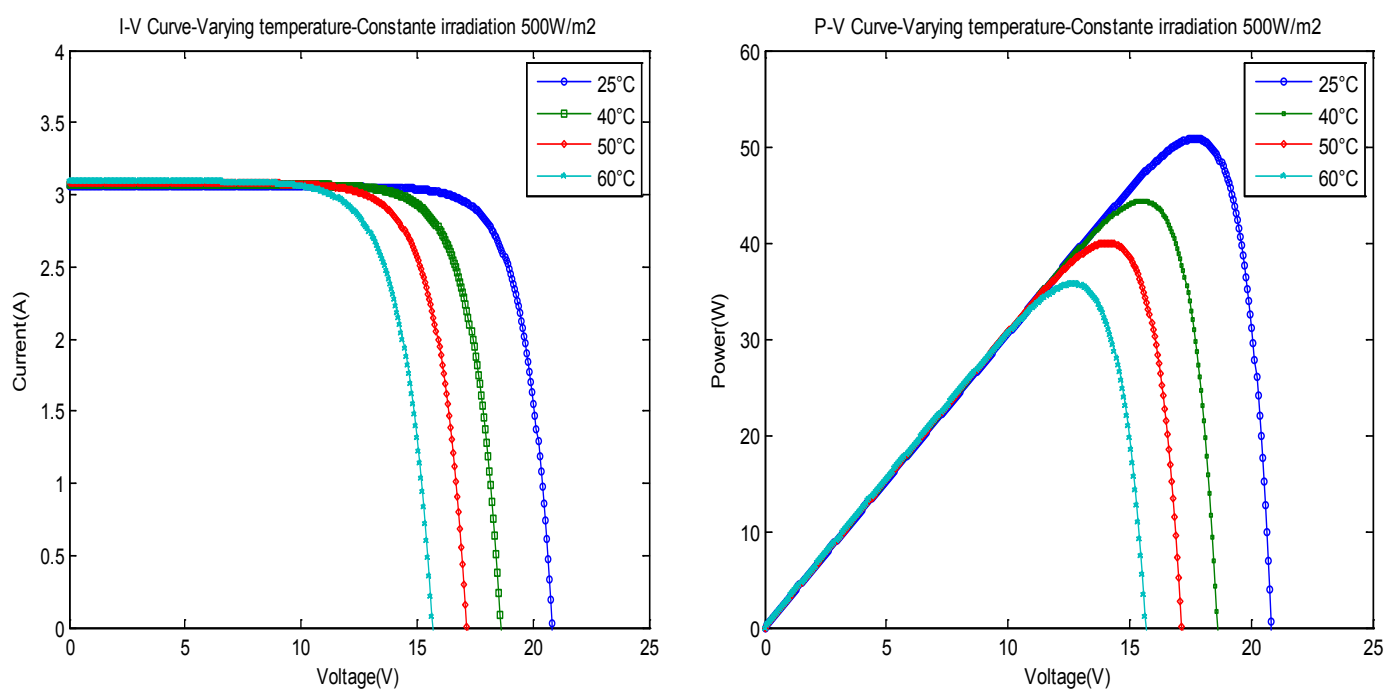

(d) Irradiation at $500 \mathrm{~W} / \mathrm{m}^{2}$.

Figure 9. The current-voltage and power-voltage characteristics of mc-Si solar module with module temperature at constant irradiation (a) $200 \mathrm{~W} / \mathrm{m}^{2}$, (b) $300 \mathrm{~W} / \mathrm{m}^{2}$, (c) $400 \mathrm{~W} / \mathrm{m}^{2}$ and (d) $500 \mathrm{~W} / \mathrm{m}^{2}$.

Likewise, the estimation of the power-voltage characteristics follows the same trend for the current-voltage characteristics. It is observed that it increases and is almost linear with the temperature of the module in the low voltage range, reached at the maximum in the range of 13.01 to $50.82 \mathrm{~W}$ for all constant irradiations.

Subsequently, it is found to decrease rapidly at a higher voltage range due to the increasing speed of photon generation with cell temperature which revealed the rapid increase in reverse saturation current as reported by [8].

The power-voltage characteristics clearly indicate a point of maximum power and the voltage at this point is less than the open circuit voltage. Likewise, the current at this point is also less than the short circuit current.

The effect of temperature dependence on photovoltaic parameters such as open circuit voltage, short circuit current, and fill factor with module tempera- 
ture between $25^{\circ} \mathrm{C}$ and $60^{\circ} \mathrm{C}$ at constant irradiations 200, 300, 400 and 500 $\mathrm{W} / \mathrm{m}^{2}$ is shown in Figure 10.

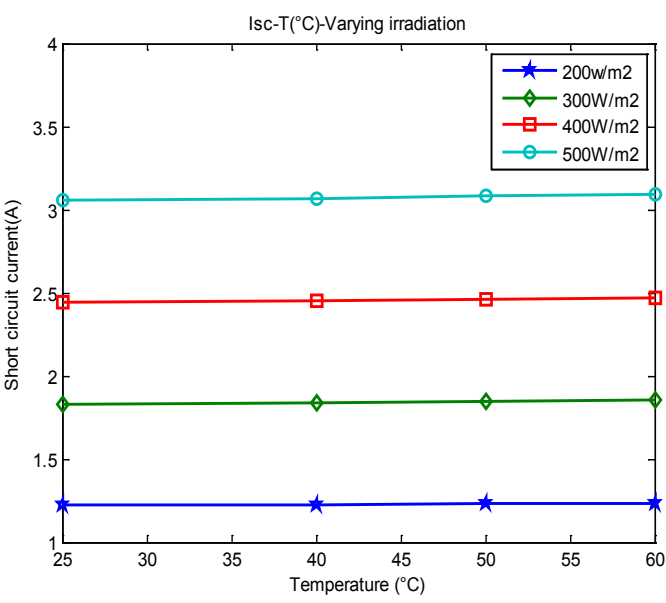

(a) Short circuit current $I_{s c}$

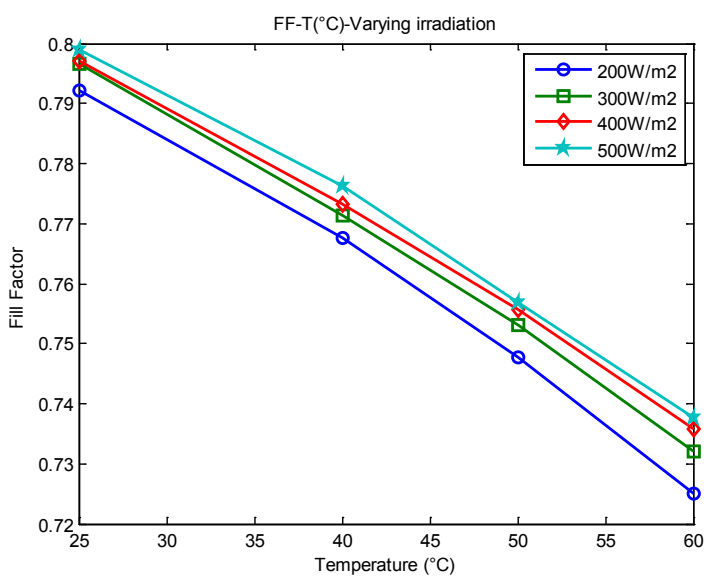

(c) Fill factor $F F$

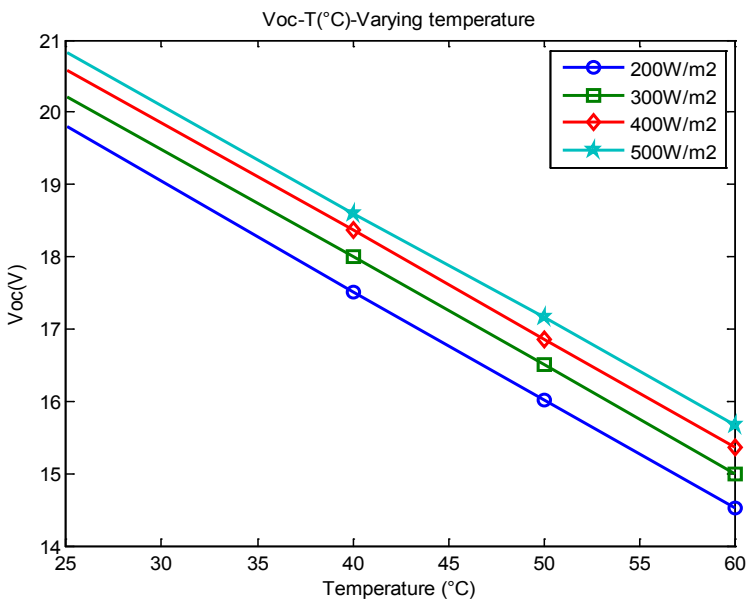

(b) Open circuit voltage $V_{o c}$

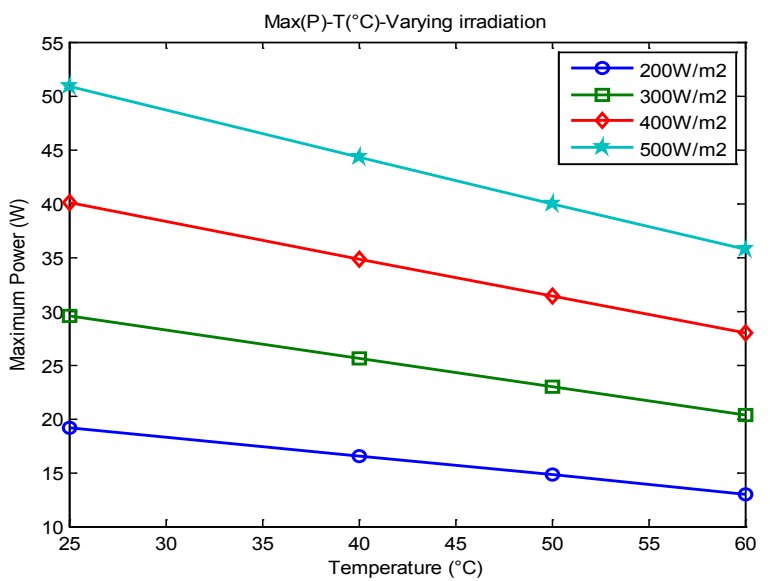

(d) Maximum Power $P_{\max }$

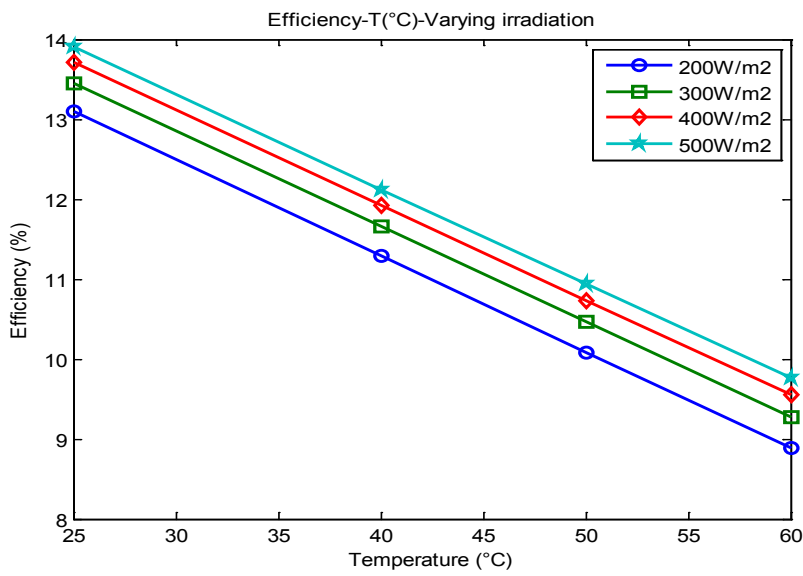

(e) Efficiency $(\eta)$

Figure 10. The variation of (a) short circuit current $\left(I_{s c}\right)$, (b) open circuit voltage $\left(V_{o c}\right)$, (c) fill factor $(F F)$, (d) Maximum Power $P_{\max }$ and (e) Efficiency of mc-Si solar Module with module temperature in the range $25^{\circ} \mathrm{C}-60^{\circ} \mathrm{C}$ at constant irradiations $200 \mathrm{~W} / \mathrm{m}^{2}, 300 \mathrm{~W} / \mathrm{m}^{2}, 400 \mathrm{~W} / \mathrm{m}^{2}$ and $500 \mathrm{~W} / \mathrm{m}^{2}$. 
It can be seen from Figure 10 that the open circuit voltage $\left(V_{o c}\right)$ and the fill factor $(F F)$ decrease with the temperature of the module while the short-circuit current $\left(I_{s c}\right)$ increases. Open circuit voltage, short circuit current, and fill factor vary with module temperature in the range $14.52-20.82 \mathrm{~V}, 1.222-3.09 \mathrm{~A}$ and 0.725 - 0.799 respectively for all constant solar irradiations.

These results are in agreement with the literature [16] [17] and their explanation is given on the basis of Equations (9) and (10) those described in previous works [13] [18].

The evolution of open circuit voltage, short circuit current, fill factor, maximum power, efficiency and their relative change of the mc-Si solar module with module temperature at constant solar irradiations of 200,300, 400 and 500 $\mathrm{W} / \mathrm{m}^{2}$ are calculated and are given by the Tables 2-6.

Table 2. The open circuit voltage and its relative change of mc-Si solar module with module temperature at different constant irradiation.

\begin{tabular}{cccccc}
\hline \multicolumn{5}{c}{ Open circuit voltage $\left(V_{o c}\right)$} \\
\hline Irradiation $\left(\mathrm{W} / \mathrm{m}^{2}\right)$ & $25^{\circ} \mathrm{C}$ & $40^{\circ} \mathrm{C}$ & $50^{\circ} \mathrm{C}$ & $60^{\circ} \mathrm{C}$ & $\left(1 / V_{o c}\right)^{*} \mathrm{~d} V_{o c} \mathrm{~d} T$ \\
\hline 200 & 19.8000 & 17.5200 & 16.0200 & 14.5200 & -0.0087 \\
300 & 20.2200 & 18.0000 & 16.5000 & 15.0000 & -0.0084 \\
400 & 20.5800 & 18.3600 & 16.8600 & 15.3600 & -0.0082 \\
500 & 20.8200 & 18.6000 & 17.1600 & 15.6600 & -0.0080 \\
\hline
\end{tabular}

Table 3. The short circuit current and its relative change of mc-Si solar module with module temperature at different constant irradiation.

\begin{tabular}{cccccc}
\hline \multicolumn{5}{c}{ Short circuit current $\left(I_{s c}\right)$} \\
\hline Irradiation $\left(\mathrm{W} / \mathrm{m}^{2}\right)$ & $25^{\circ} \mathrm{C}$ & $40^{\circ} \mathrm{C}$ & $50^{\circ} \mathrm{C}$ & $60^{\circ} \mathrm{C}$ & $\left(1 / I_{s c}\right)^{*} \mathrm{~d} I_{s c} \mathrm{~d} T$ \\
\hline 200 & 1.2220 & 1.2280 & 1.2320 & 1.2360 & 0.0003 \\
300 & 1.8330 & 1.8420 & 1.8480 & 1.8540 & 0.0003 \\
400 & 2.4440 & 2.4560 & 2.4640 & 2.4720 & 0.0003 \\
500 & 3.0550 & 3.0700 & 3.0800 & 3.0900 & 0.0003 \\
\hline
\end{tabular}

Table 4. The maximum output power $P_{\max }$ and its relative change of mc-Si solar module with module temperature at different constant irradiation.

\begin{tabular}{cccccc}
\hline \multicolumn{5}{c}{ Maximum Power $(\mathrm{W})$} \\
\hline Irradiation $\left(\mathrm{W} / \mathrm{m}^{2}\right)$ & $25^{\circ} \mathrm{C}$ & $40^{\circ} \mathrm{C}$ & $50^{\circ} \mathrm{C}$ & $60^{\circ} \mathrm{C}$ & $\left(1 / P_{\max }\right)^{*} \mathrm{~d} P_{\max } / \mathrm{d} T\left(1 /{ }^{\circ} \mathrm{C}\right)$ \\
\hline 200 & 19.1658 & 16.5158 & 14.7577 & 13.0110 & -0.0109 \\
300 & 29.5222 & 25.5784 & 22.9604 & 20.3580 & -0.0104 \\
400 & 40.0933 & 34.8664 & 31.3947 & 27.9410 & -0.0102 \\
500 & 50.8234 & 44.3204 & 39.9995 & 35.6985 & -0.0099 \\
\hline
\end{tabular}


Table 5. The fill factor and its relative change of mc-Si solar module with module temperature at different constant irradiation.

\begin{tabular}{cccccc}
\hline \multicolumn{5}{c}{ Fill Factor } \\
\hline Irradiation $\left(\mathrm{W} / \mathrm{m}^{2}\right)$ & $25^{\circ} \mathrm{C}$ & $40^{\circ} \mathrm{C}$ & $50^{\circ} \mathrm{C}$ & $60^{\circ} \mathrm{C}$ & $(1 / F F)^{\star} \mathrm{d} F F / \mathrm{d} T\left(1 /{ }^{\circ} \mathrm{C}\right)$ \\
\hline 200 & 0.7921 & 0.7677 & 0.7477 & 0.7250 & -0.0025 \\
300 & 0.7965 & 0.7715 & 0.7530 & 0.7320 & -0.0024 \\
400 & 0.7971 & 0.7732 & 0.7557 & 0.7359 & -0.0023 \\
500 & 0.7990 & 0.7762 & 0.7568 & 0.7377 & -0.0022 \\
\hline
\end{tabular}

Table 6. The efficiency and its change of mc-Si solar module with module temperature at different constant irradiation.

\begin{tabular}{cccccc}
\hline \multicolumn{5}{c}{ Efficiency (\%) } \\
\hline Irradiation $\left(\mathrm{W} / \mathrm{m}^{2}\right)$ & $25^{\circ} \mathrm{C}$ & $40^{\circ} \mathrm{C}$ & $50^{\circ} \mathrm{C}$ & $60^{\circ} \mathrm{C}$ & $(1 / \eta)(\mathrm{d} \eta / \mathrm{d} T)\left(1 /{ }^{\circ} \mathrm{C}\right)$ \\
\hline 200 & 13.1003 & 11.2890 & 10.0873 & 8.8933 & -0.0109 \\
300 & 13.4528 & 11.6557 & 10.4627 & 9.2768 & -0.0104 \\
400 & 13.7024 & 11.9160 & 10.7296 & 9.5492 & -0.0102 \\
500 & 13.8957 & 12.1177 & 10.9363 & 9.7604 & -0.0099 \\
\hline
\end{tabular}

From Equation (8), the open circuit voltage is reduced when the temperature increases, in fact, $E_{g}$ decreases with the temperature [19]. The short-circuit current $\left(I_{s c}\right)$ is proportional to the number of charge carriers generated and their mobility. This strongly depends on the charge carrier generation rate and the diffusion length. The rate of charge carrier generation increases with cell temperature and consequently the short-circuit current increases as indicated by [18] [20] but only slightly [21].

We find that the maximum power $P_{\max }$ decreases with the temperature of the module at all constant solar irradiations, as illustrated in Table 4 which revealed a decrease in voltage with the temperature of the module. We deduce from Equation (9) that the fill factor decreases with module temperature due to the change in the corresponding open circuit voltage and short circuit current.

It is also seen from Table 6 that the efficiency decreases with module temperature at all constant irradiations due to the decrease in the corresponding open circuit voltage and fill factor. According to Equation (11) and as the quantity $\left(T_{c}-T_{r e f}\right)$ increases with cell temperature, this leads to an increase in efficiency of module.

\section{Conclusion}

In this present article, the effect of module temperature on the photovoltaic parameters of the mc-Si photovoltaic module is reported by using a step-by-step procedure for simulating a PV module with Tag tools, with user-friendly icons and dialogs in Matlab/Simulink block libraries. This modeling procedure was carried out with a module temperature between $25^{\circ} \mathrm{C}$ and $60^{\circ} \mathrm{C}$ at constant solar 
irradiations of $200,300,400$ and $500 \mathrm{~W} / \mathrm{m}^{2}$. The results show that the module temperature has a significant impact on the photovoltaic parameters and that it controls the quality and the performance of the mc-Si solar panel.

The open circuit voltage $\left(V_{o c}\right)$, the maximum power point $\left(P_{\max }\right)$, the fill factor $(F F)$ and the efficiency $(\eta)$ of the mc-Si solar module are decreased with the temperature of the module, while the short-circuit current $\left(I_{s c}\right)$ increases slightly. The temperature coefficient of open circuit voltage, fill factor, maximum output power and efficiency is negative while it is positive for short circuit current. The relative variation of the photovoltaic parameters with the temperature is also calculated and found from $-0.0080 /{ }^{\circ} \mathrm{C}$ to $-0.0087 /{ }^{\circ} \mathrm{C},-0.0022$ to $-0.0025 /{ }^{\circ} \mathrm{C}$, $-0.001 /{ }^{\circ} \mathrm{C},-0.001 /{ }^{\circ} \mathrm{C}$ and $0.00032 /{ }^{\circ} \mathrm{C}$ for open circuit voltage, fill factor, maximum output power, efficiency and short circuit current respectively. These results are in good agreement with the available literature. This research can extend to the influence of irradiance on the parameters described previously.

\section{Conflicts of Interest}

The authors declare no conflicts of interest regarding the publication of this paper.

\section{References}

[1] Cuce, E., Cuce, P.M. and Bali, T. (2013) An Experimental Analysis of Illumination Intensity and Temperature Dependency of Photovoltaic Cell Parameters. Applied Energy, 111, 374-382. https://doi.org/10.1016/j.apenergy.2013.05.025

[2] Cai, W., Chao, F., Long, T.J., Xiong, L.D., Fu, H.S. and Gang, X.Z. (2012) The Influence of Environment Temperatures on Single Crystalline and Polycrystalline Silicon Solar Cell Performance. Science China Physics, Mechanics \& Astronomy, 55, 235-241. https://doi.org/10.1007/s11433-011-4619-z

[3] Khan, F., Singh, S.N. and Husain, M. (2010) Effect of Illumination Intensity on Cell Parameters of Silicon Solar Cell. Solar Energy Materials and Solar Cells, 94, 1473-1476. https://doi.org/10.1016/j.solmat.2010.03.018

[4] Choi, P., Kim, H., Baek, D. and Choi, B. (2012) A Study on the Electrical Characteristic Analysis of C-Si Solar Cell Diodes. Journal of Semiconductor Technology and Science, 12, 59-65. https://doi.org/10.5573/ISTS.2012.12.1.59

[5] Tsuno, Y., Hishikawa, Y. and Kurokawa, K. (2005) Temperature and Irradiance Dependence of the I-V Curves of Various Kinds of Solar Cells. 15th International Photovoltaic Science \& Engineering Conference, PVSEC-15, Shanghai, 10-15 October 2005, 422-423.

[6] Sabry, M. and Ghitas, A.E. (2008) Influence of Temperature on Methods for Determining Silicon Solar Cell Series Resistance. The Journal of Solar Energy Engineering, 129, 331-335. https://doi.org/10.1115/1.2735350

[7] Dubey, S., Sarvaiya, J.N. and Seshadri, B. (2013) Temperature Dependent Photovoltaic (PV) Efficiency and Its Effect on PV Production in the World: A Review. Energy Procedia, 33, 311-321. https://doi.org/10.1016/j.egypro.2013.05.072

[8] Arjyadhara, P., Ali, S.M. and Chitralekha, J. (2013) Analysis of Solar PV Cell Performance with Changing Irradiance and Temperature. International Journal of Engineering and Computer Science, 2, 214-220. 
[9] Pandiarajan, N. and Muthu, R. (2011) Mathematical Modeling of Photovoltaic Module with Simulink. International Conference on Electrical Energy Systems (ICEES 2011), Chennai, 3-5 January 2011, 6. https://doi.org/10.1109/ICEES.2011.5725339

[10] Tu, H.-L.T. and Su, Y.-J. (2008) Development of Generalized Photovoltaic Model Using MATLAB/SIMULINK. Proceedings of the World Congress on Engineering and Computer Science, San Francisco, 22-24 October 2008, 6.

[11] Salmi, T., Bouzguenda, M., Gastli, A. and Masmoudi, A. (2012) Matlab/Simulink Based Modelling of Solar Photovoltaic Cell. International Journal of Renewable Energy Research, 2, 6.

[12] Kalogirou, S. (2009) Solar Energy Engineering: Processes and Systems. Academic Press, Cambridge, $48 \mathrm{p}$.

[13] Singh, P. and Ravindra, N.M. (2012) Temperature Dependence of Solar Cell Performance an Analysis. Solar Energy Materials and Solar Cells, 101, 36-45. https://doi.org/10.1016/j.solmat.2012.02.019

[14] Sajjad, U., Amer, M., Ali, H.M., Dahiya, A. and Abbas, N. (2019) Cost Effective Cooling of Photovoltaic Modules to Improve Efficiency. Case Studies in Thermal Engineering, 14, Article ID: 100420. https://doi.org/10.1016/j.csite.2019.100420

[15] https://www.enfsolar.com/pv/panel-datasheet/crystalline/30444

[16] Fesharaki, V.J., Dehghani, M. and Fesharaki, J.J. (2011) The Effect of Temperature on Photovoltaic Cell Efficiency. Proceedings of the 1st International Conference on Emerging Trends in Energy Conservation, Tehran, 20-22 November 2011, 6.

[17] Emery, K. and Osterwald, C. (1987) Measurement of Photovoltaic Device Current as a Function of Voltage, Temperature, Intensity and Spectrum. Solar Cells, 21, 313-327. https://doi.org/10.1016/0379-6787(87)90130-X

[18] Lammert, M.D. and Schwarts, R.J. (1997) The Integrated Back Contact Solar Cell: A Silicon Solar Cell for Use in Concentrated Sunlight. IEEE Transactions on Electron Devices, 24, 337-342. https://doi.org/10.1109/T-ED.1977.18738

[19] Chander, S., Purohit, A., Sharma, A., Arvind, Nehra, S.P. and Dhaka, M.S. (2015) A Study on Photovoltaic Parameters of Mono-Crystalline Silicon Solar Cell with Cell Temperature. Energy Reports, 1, 104-109. https://doi.org/10.1016/j.egyr.2015.03.004

[20] Arora, N.D. and Hauser, J.R. (1982) Temperature Dependence of Silicon Solar Cell Characteristics. Solar Energy Materials, 6, 151-158. https://doi.org/10.1016/0165-1633(82)90016-8

[21] Zondag, H.A. (2008) Flat-Plate PV-Thermal Collectors and Systems: A Review. Renewable and Sustainable Energy Reviews, 12, 891-959.

https://doi.org/10.1016/j.rser.2005.12.012 